\title{
Effects of biochar on soil water and temperature, nutrients, and yield of maize/soybean and maize/peanut intercropping systems**
}

\author{
Ce Luan ${ }^{1,2}$,Wei He ${ }^{2}, X u S^{1}$, Xuanming Wang ${ }^{1}$, Yikui Bai ${ }^{1}$, and Lixue Wang ${ }^{1}$ \\ ${ }^{1}$ College of Water Resource, Shenyang Agricultural University, Shenyang 110866, China \\ ${ }^{2}$ College of Hydraulic Engineering, Liaoning Vocational College of Ecological Engineering, Shenyang 110866, China
}

Received August 12, 2021; accepted November 22, 2021

\begin{abstract}
A two-year field experiment was conducted to evaluate the ability of biochar to improve the soil environment of intercropping systems. There were two planting systems (maize/ soybean, maize/peanut intercropping) coupled with three biochar application rates $\left(0,15\right.$, and $\left.30 \mathrm{tha}^{-1}\right)$. Changes in the soil water content, soil bulk density, temperature, soil nutrients and yield were recorded. Under the influence of rainfall, biochar significantly increased soil water storage at the $0-30 \mathrm{~cm}$ soil layer. The maximum increment of soil water storage was $15.5 \%$ with the maize/peanut intercropping at $15 \mathrm{t} \mathrm{ha}^{-1}$ treatment at the tassel stage. Both biochar treatments significantly increased the soil effective accumulated temperature at the seedling stage and jointing stage. The greatest increment in soil effective accumulated temperature was achieved using the maize/peanut intercropping at $15 \mathrm{t} \mathrm{ha}^{-1}$ treatment. The effects of biochar on soil effective accumulated temperature were weakened at the tasselling, grain filling and mature stages. After biochar application, the soil mineral nitrogen content was significantly reduced at the seeding stage, but significantly increased by $25.2-48.9 \%$ at the tasselling and grain filling stages. The soil ammonium and nitrate nitrogen content of the soybean and peanut ridges was significantly higher than those of the corn ridges. The total yield of maize/soybean increased by $12.8-13.7 \%$ and the total yield of maize/peanut intercropping increased by $15.9-18.0 \%$ relative to the treatment without biochar. Therefore, both $15 \mathrm{tha}^{-1}$ and $30 \mathrm{tha}^{-1}$ effectively regulated the soil water, nutrient and temperature at the jointing, tasselling and grain filling stages, which enhanced the positive effects of intercropping on crop yield. From an analysis of the yield results, it was found that biochar may be more significant in the maize/peanut intercropping system.

Keyw ords: biochar, intercropping, water storage, effective accumulated temperature, mineral nitrogen
\end{abstract}

*Corresponding author e-mail: leonjosip.baiyikui@syau.edu.cn **This work was supported by the Key R\&D Programme of Liaoning under Grant 2018103007; the Liaoning Natural Science Fund under Grant 2019-ZD-0705 (2019-2021).

\section{INTRODUCTION}

Intercropping is an important agricultural planting technique that improves resource utilization efficiency through interactions between different crop species (Chen et al., 2010). The implementation of a reasonable intercropping strategy could improve the efficiency with which plants utilize light, temperature, fertilizer, water and other natural resources, it could also reduce the risk of pests, diseases, and weed competition and increase the yield per unit area (Oswald et al., 2002; Hussain et al., 2020). The annual area in China sown under intercropping conditions is more than $2.8 \times 10^{7}$ ha, among which the area of legume intercropping exceeds $1 \times 10^{7}$ ha (Miao et al., 2011). Therefore, continuous improvement in the production of the intercropping planting model is important to ensure food security.

Because legumes can obtain nitrogen from the atmosphere through biological nitrogen fixation, the intercropping of Gramineae and Leguminosae species can enhance yields, this has been confirmed by previous studies (Green et al., 2019). When intercropped with grasses, legumes can act as nutrient donors for grass crops, thereby increasing the nitrogen utilization rate (Pirhofer et al., 2012). In addition, the intercropping of Gramineae species and legumes allows for the optimization of the temporal and spatial growth patterns of the above ground and underground parts, which has the potential not only to promote the efficient use of resources such as light and

(C) 2021 Institute of Agrophysics, Polish Academy of Sciences 
heat but it could also increase the efficiency with which plants utilize nutrients and water through interactions within the rhizosphere (Sekiya et al., 2011). However, all crops in the late growth stage of both gramineous and leguminous growth also require large amounts of nutrients. Given that the nutrient requirements exceed supply, gramineous crops suppress the growth of leguminous crops, thereby reducing yields. Liao (2019) showed that biochar amendment could alter the soil bacterial community by assimilating plant-derived carbon, which plays an important role in nutrient cycling and in improving plant performance in intercropping systems in the late growth stage in a legume-based intercropping system. Liu (2020) found that the dry matter accumulation of peanuts during the maturity stage was $43.97 \%$ lower than that produced by monocropping, in a corn/peanut intercropping experiment. Zhang et al. (2017) showed that the yield resulting from soybean and peanut intercropping with corn was reduced by 8.4 and $48.7 \%$, respectively, compared to the single cropping of soybean and peanut. Therefore, it is of great significance to continuously enhance the soil nutrient supply during the critical growth period of plants in order to balance resource competition in intercropping systems.

Biochar is widely used in agriculture as a soil amendment to improve soil quality and increase crop productivity. Biochar has a rich pore structure, large specific surface area, and a high surface charge density, which has the potential to reduce nutrient leaching, promote crop nutrient absorption, and subsequently improve crop productivity (Lehmann et al., 2003; Sohi et al., 2010). Biochar can improve the utilization efficiency of soil nutrients (e.g., $\mathrm{Al}, \mathrm{Ca}, \mathrm{Mg}, \mathrm{B}$ and Mo) by moderately increasing soil $\mathrm{pH}$ and the availability of trace elements, it can also inhibit the release of $\mathrm{NO}, \mathrm{N}_{2} \mathrm{O}$, and $\mathrm{N}_{2}$ resulting from denitrification by stabilizing the soil structure and improving the release of soluble carbon, nitrogen loss is also reduced by increasing the soil nutrient adsorption capacity (Abel et al., 2013; Major et al., 2010). In low organic matter loam soils, adding 20 tha $^{-1}$ of biochar without applying nitrogen increased the maize yield by $15.8 \%$, while adding $40 \mathrm{tha}^{-1}$ of biochar increased the yield by $7.3 \%$. When applying nitrogen fertilizer, adding $20 \mathrm{tha}^{-1}$ of biochar increased the maize yield by $8.8 \%$, while adding $40 \mathrm{tha}^{-1}$ of biochar increased the maize yield by $12.1 \%$ (Liu et al., 2013). Dai et al. (2019) showed that the corn yield increased significantly with the increase in the soil content of biochar. Previous studies designed to determine the impact of biochar on crop productivity have mainly focused on single planting systems. By contrast, few studies have examined the ability of biochar to alleviate water-nutrient competition resulting from intercropping planting techniques.

The aim of this experiment was to characterize the effects of biochar on crop yield, soil water, soil temperature, and nutrients under an intercropping system to reveal the positive effects of biochar on that system. Another research goal was to establish whether biochar can enhance the nutrient supply in the grain filling and maturing stage of crop growth and alleviate the fierce nutrient competition between crops in the intercropping system.

\section{MATERIALS AND METHODS}

The experiment was carried out from May 2019 to October 2020 at the interdisciplinary research centre of the College of Water Resources at Shenyang Agricultural University. The area is located in the east of Shenyang City ( $41^{\circ} 84^{\prime} \mathrm{N}, 123^{\circ} 57^{\prime} \mathrm{E}, 44.7 \mathrm{~m}$ above sea level). It has a temperate continental monsoon climate with cold and dry winters, and high-temperature and rainy summers. The soil texture in this area is a brown loam soil. The average annual precipitation is $721.9 \mathrm{~mm}$. Precipitation in the summer accounted for almost $70 \%$ of the total precipitation recorded. The physical and chemical properties of the soil are as follows: organic carbon; $31.5 \mathrm{~g} \mathrm{~kg}^{-1}$, total nitrogen; $1.0 \mathrm{~g} \mathrm{~kg}^{-1}$, total phosphorus; $8.1 \mathrm{~g} \mathrm{~kg}^{-1}$, total potassium; $15.7 \mathrm{~g} \mathrm{~kg}^{-1}$. The two-year precipitation record observed during the experiments is shown in Fig. 1.

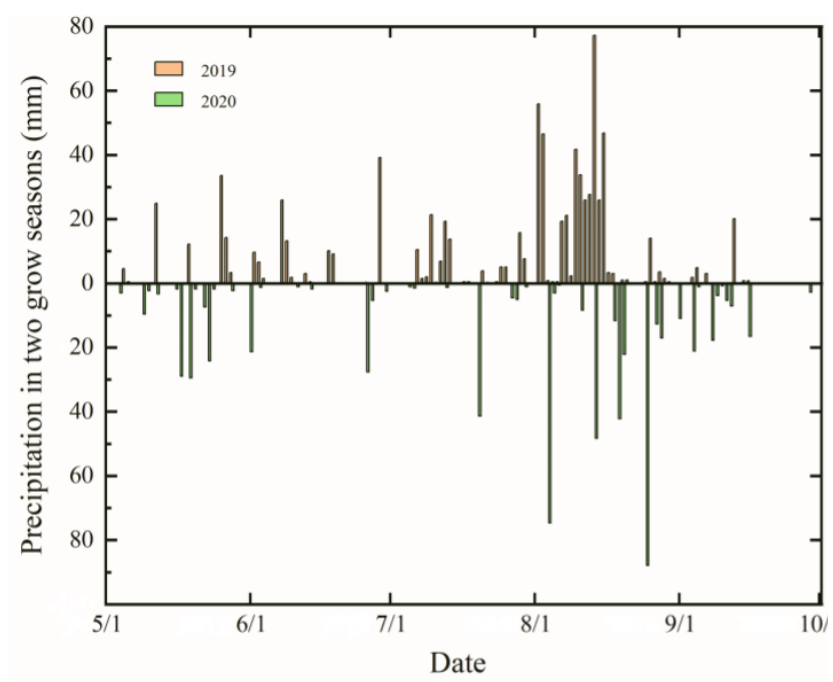

Fig. 1. Precipitation in the two growth seasons.

The field experiments were conducted in the form of a two-factor randomized block design, with two levels of intercropping planting techniques and three levels of biochar applied for six treatments over three replicates. The intercropping planting techniques used for the first factor, included maize/soybean intercropping (MS), and maize/peanut intercropping (MP). The second factor biochar application rates were as follows: 0 tha $^{-1}\left(\mathrm{~T}_{0}\right), 15 \mathrm{tha}^{-1}\left(\mathrm{~T}_{1}\right)$, and $30 \mathrm{tha}^{-1}\left(\mathrm{~T}_{2}\right)$.

The plot sizes of each plot were $3 \times 6 \mathrm{~m}^{2}$ under plastic film mulching on every ridge as shown in Fig. 2. Corn was sown at a density of $6.67 \times 10^{4}$ seeds ha ${ }^{-1}$, and soybeans and peanuts were both sown at a density of $12 \times 10^{4}$ seeds ha ${ }^{-1}$. Biochar was prepared through the anaerobic pyrolysis of corn stover at a high temperature of $450^{\circ} \mathrm{C}$ with a residence time of $18 \mathrm{~min}$. The basic physical and chemical properties of biochar are organic carbon $515 \mathrm{~g} \mathrm{~kg}^{-1}$, total nitrogen $10.2 \mathrm{~g} \mathrm{~kg}^{-1}$, total phosphorus $8.1 \mathrm{~g} \mathrm{~kg}^{-1}$ and total potassium $15.7 \mathrm{~g} \mathrm{~kg}^{-1}$. Before 
starting the experiment, biochar was distributed evenly and stirred repeatedly with a shovel to mix it with the topsoil $(0-30 \mathrm{~cm})$. In both years of the study, the cultivars of corn, soybean and peanut respectively were Liangyu 777, Dongdou No. 1, and Baisha 308. The crops were planted in a single row per ridge. The width of the ridges was $20 \mathrm{~cm}$, while the distance between the two ridges was $15 \mathrm{~cm}$. The height of the ridges was $10 \mathrm{~cm}$, and the length of the ridge was $6 \mathrm{~m}$.

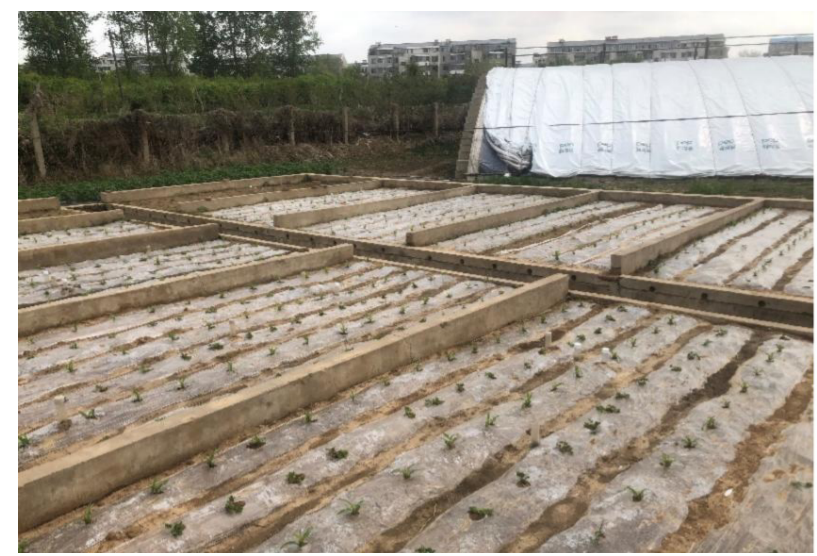

Fig. 2. Experimental site.

The numbers of corn and legume (soybean and peanut) plants in each ridge were 20 and 36 , respectively. During the test period, no irrigation water was supplied; thus rainfall was the only supplementary water source. Before sowing, nitrogen fertilizer $280 \mathrm{~kg} \mathrm{ha}^{-1}$, phosphorus $135 \mathrm{~kg} \mathrm{ha}^{-1}$, and potassium $155 \mathrm{~kg} \mathrm{ha}^{-1}$ were applied to all plots. The treatments are shown in Table 1.

Table 1. Experimental design

\begin{tabular}{lccc}
\hline \multirow{2}{*}{ Intercropping system } & \multicolumn{3}{c}{ Biochar treatment } \\
\cline { 2 - 4 } & $\mathrm{T}_{0}$ & $\mathrm{~T}_{1}$ & $\mathrm{~T}_{2}$ \\
\hline Maize+soybean & $\mathrm{MST}_{0}$ & $\mathrm{MST}_{1}$ & $\mathrm{MST}_{2}$ \\
Maize+peanut & $\mathrm{MPT}_{0}$ & $\mathrm{MPT}_{1}$ & $\mathrm{MPT}_{2}$ \\
\hline
\end{tabular}

$\mathrm{T}_{0}-\left(0\right.$ tha $\left.^{-1}\right), \mathrm{T}_{1}-\left(15 \mathrm{tha}^{-1}\right), \mathrm{T}_{2}-\left(30 \mathrm{tha}^{-1}\right)$

TDR (Diviner 2000 by SenTek Corporation, Australia) was used to measure soil volumetric moisture content at soil depths of 10, 20, 30, 40, 50, $60 \mathrm{~cm}$, and 3 Trime tubes were buried in each plot. To calculate the soil water storage $(S W S)$ value and analyse the differences between the treatments in each growth period, we first calculated the average bulk density of soil at the $0-30 \mathrm{~cm}$ and $30-60 \mathrm{~cm}$ depth in each growth period. The soil bulk density was measured once every growth period using the ring knife method (Wu et al., 2019). Soil bulk density was only determined in 2019 and it was also used to calculate SWS in 2020. Soil water storage was calculated using Eq. (1) by Milly et al. (1994):

$$
S W S=\frac{\theta_{m} \rho_{b} h}{\rho_{w}},
$$

where: $S W S$ is the average soil water storage capacity in each period $(\mathrm{mm}), \theta_{m}$ is the soil volumetric moisture content $(\%), \rho_{b}$ is the soil bulk density $\left(\mathrm{g} \mathrm{cm}^{-3}\right), h$ is the depth of the soil layer (mm) and $\rho_{w}$ is the water density $\left(\mathrm{g} \mathrm{cm}^{-3}\right)$. The $S W S$ for each treatment between 0 and $60 \mathrm{~cm}$ is the sum of SWS for each soil layer.

The soil temperatures at different depths of $5,10,15,20$ and $25 \mathrm{~cm}$, were observed at 6:00 and 14:00 with a curved tube ground thermometer. The soil effective accumulated temperature (SEAT) was calculated using Eq. (2) by Xu et al. (2020):

$$
K=N(T-10),
$$

where: $K$ is the SEAT $\left({ }^{\circ} \mathrm{C}\right), N$ is the duration of different growth periods (d), $T$ is the average soil temperature, and $10^{\circ} \mathrm{C}$ is the effective threshold temperature for crop growth.

In each growth period, soil samples from the corn and soybean (or peanut) ridge were taken at a $10-20 \mathrm{~cm}$ depth. Soil samples, derived from five randomly selected points per plot were passed through a $2 \mathrm{~mm}$ sieve after blending, and air-dried in a laboratory. Following this, $5 \mathrm{~g}$ of each soil sample was extracted using $50 \mathrm{ml}$ of $2 \mathrm{M} \mathrm{KCl}$ solution. Concentrations of $\mathrm{NH}_{4}{ }^{+}-\mathrm{N}$ and $\mathrm{NO}_{3}^{-}-\mathrm{N}$ were determined using the AA3 Continuous Flow Analytical System manufactured by Bran + Luebbe from Germany.

At the end of each growth stage, seeds of corns, soybeans and peanuts were air-dried outdoors for 10-13 days and the yields were calculated based on a $14 \%$ moisture content.

The growth stages in this experiment were respectively, the seedling stage, jointing stage, tasselling stage, grain filling stage and maturity stage based on the main corn crop.

All data were subjected to analysis using a two-way variance (ANOVA) which utilized SAS9.3 software. The separation of the means was performed using the least significant difference (LSD). The figures were plotted using Origin 2021.

\section{RESULTS}

Table 2 shows that in the maize/soybean intercropping system, compared with the $T_{0}$ treatment, the $T_{1}$ and $\mathrm{T}_{2}$ treatments increased the maize yield by 14.2 and $13.3 \%$, respectively. The soybean yield increased by 4.84 and $14.52 \%$, respectively, and the total yield increased by 12.8 and $13.8 \%$ with increasing biochar rates, respectively (2019). However, $T_{2}$ decreased the maize yield in 2020. In the maize/peanut intercropping system, the maize yield was also significantly increased through biochar application, the average peanut yield increased by 19.1 and $32.0 \%$, and the total yield increased by 13.8 and $11.8 \%$ with increasing biochar application, respectively, as compared with the $\mathrm{T}_{0}$ treatment during the two growing seasons. It may be observed that biochar addition significantly increased the overall yield of the intercropping system, and the yieldincreasing effect of biochar with regard to peanuts reached a very significant level $(\mathrm{p}<0.01)$. In the case of the maize yield, the rate of increase tapered off with the increase in the amount of biochar added. 
Table 2. Maize and legume (soybean or peanut) yields in the intercropping systems during the two grow seasons

\begin{tabular}{lccccccccc}
\hline $\begin{array}{l}\text { Intercropping } \\
\text { mode }\end{array}$ & Biochar & $\begin{array}{c}\text { Maize } \\
\left(\mathrm{tha}^{-1}\right)\end{array}$ & $\begin{array}{c}\text { Soybean } \\
\left(\mathrm{t} \mathrm{ha}^{-1}\right)\end{array}$ & $\begin{array}{c}\text { Peanut } \\
\left(\mathrm{tha}^{-1}\right)\end{array}$ & $\begin{array}{c}\text { Total } \\
\left(\mathrm{tha}^{-1}\right)\end{array}$ & $\begin{array}{c}\text { Maize } \\
\left(\mathrm{tha}^{-1}\right)\end{array}$ & $\begin{array}{c}\text { Soybean } \\
\left(\mathrm{tha}^{-1}\right)\end{array}$ & $\begin{array}{c}\text { Peanut } \\
\left(\mathrm{tha}^{-1}\right)\end{array}$ & $\begin{array}{c}\text { Total } \\
\left(\mathrm{tha}^{-1}\right)\end{array}$ \\
\hline \multirow{2}{*}{ Maize+soybean } & $\mathrm{T}_{0}$ & $6.42 \mathrm{~b}$ & $1.24 \mathrm{~b}$ & - & $7.66 \mathrm{~b}$ & $6.21 \mathrm{ab}$ & $1.30 \mathrm{~b}$ & - & $7.51 \mathrm{~b}$ \\
& $\mathrm{~T}_{1}$ & $7.33 \mathrm{a}$ & $1.30 \mathrm{ab}$ & - & $8.64 \mathrm{a}$ & $7.60 \mathrm{a}$ & $1.32 \mathrm{~b}$ & - & $8.92 \mathrm{a}$ \\
& $\mathrm{T}_{2}$ & $7.28 \mathrm{a}$ & $1.42 \mathrm{a}$ & - & $8.71 \mathrm{a}$ & $5.56 \mathrm{~b}$ & $1.46 \mathrm{a}$ & - & $8.02 \mathrm{ab}$ \\
Maize+peanut & $\mathrm{T}_{0}$ & $6.19 \mathrm{~b}$ & - & $1.05 \mathrm{c}$ & $7.25 \mathrm{~b}$ & $6.45 \mathrm{~b}$ & - & $1.11 \mathrm{c}$ & $7.55 \mathrm{~b}$ \\
& $\mathrm{~T}_{1}$ & $7.12 \mathrm{a}$ & - & $1.28 \mathrm{~b}$ & $8.40 \mathrm{a}$ & $7.14 \mathrm{a}$ & - & $1.29 \mathrm{~b}$ & $8.43 \mathrm{a}$ \\
Intercropping system & $\mathrm{T}_{2}$ & $7.16 \mathrm{a}$ & - & $1.40 \mathrm{a}$ & $8.56 \mathrm{a}$ & $6.52 \mathrm{~b}$ & - & $1.45 \mathrm{a}$ & $7.97 \mathrm{ab}$ \\
Biochar & & $\mathrm{ns}$ & - & - & $\mathrm{ns}$ & $\mathrm{ns}$ & - & - & $\mathrm{ns}$ \\
Intercropping & & $* *$ & $*$ & $* *$ & $* *$ & $* *$ & $*$ & $* *$ & $*$ \\
\hline
\end{tabular}

Different letters mean significant difference at $\mathrm{p}<0.05, *$ significant at $\mathrm{p}<0.05, * *$ significant at $\mathrm{p}<0.01$.

Table 3. Soil bulk density at different soil layers in the intercropping systems

\begin{tabular}{|c|c|c|c|c|c|c|}
\hline \multirow{3}{*}{$\begin{array}{l}\text { Soil depth } \\
(\mathrm{cm})\end{array}$} & \multirow{3}{*}{ Treatment } & \multicolumn{5}{|c|}{ Soil bulk density $\left(\mathrm{g} \mathrm{cm}^{-3}\right)$} \\
\hline & & Seedling & Jointing & Tasselling & Grain filling & Mature \\
\hline & & \multicolumn{5}{|c|}{ Stage } \\
\hline \multirow{6}{*}{$0-30$} & $\mathrm{MST}_{0}$ & 1.28 & 1.36 & 1.42 & 1.47 & 1.48 \\
\hline & $\mathrm{MST}_{1}$ & 1.26 & 1.35 & 1.41 & 1.46 & 1.48 \\
\hline & $\mathrm{MST}_{2}$ & 1.25 & 1.35 & 1.39 & 1.46 & 1.46 \\
\hline & $\mathrm{MPT}_{0}$ & 1.29 & 1.36 & 1.42 & 1.47 & 1.47 \\
\hline & $\mathrm{MPT}_{1}$ & 1.28 & 1.34 & 1.41 & 1.46 & 1.45 \\
\hline & $\mathrm{MPT}_{2}$ & 1.24 & 1.33 & 1.40 & 1.45 & 1.45 \\
\hline \multirow{6}{*}{$30-60$} & $\mathrm{MST}_{0}$ & 1.57 & 1.57 & 1.57 & 1.56 & 1.57 \\
\hline & $\mathrm{MST}_{1}$ & 1.57 & 1.57 & 1.57 & 1.57 & 1.58 \\
\hline & $\mathrm{MST}_{2}$ & 1.56 & 1.55 & 1.55 & 1.55 & 1.56 \\
\hline & $\mathrm{MPT}_{0}$ & 1.57 & 1.58 & 1.58 & 1.57 & 1.57 \\
\hline & $\mathrm{MPT}_{1}$ & 1.56 & 1.58 & 1.56 & 1.58 & 1.57 \\
\hline & $\mathrm{MPT}_{2}$ & 1.56 & 1.57 & 1.56 & 1.57 & 1.56 \\
\hline
\end{tabular}

Table 4. Soil water storage as affected by biochar in the intercropping systems

\begin{tabular}{|c|c|c|c|c|c|c|c|c|c|c|c|}
\hline \multirow{3}{*}{$\begin{array}{l}\text { Soil } \\
\text { depth } \\
(\mathrm{cm})\end{array}$} & \multirow{3}{*}{ Treatment } & \multicolumn{5}{|c|}{ Soil water storage in $2019(\mathrm{~mm})$} & \multicolumn{5}{|c|}{ Soil water storage in $2020(\mathrm{~mm})$} \\
\hline & & Seedling & Jointing & Tasselling & $\begin{array}{l}\text { Grain } \\
\text { filling }\end{array}$ & Mature & Seedling & Jointing & Tasselling & $\begin{array}{l}\text { Grain } \\
\text { filling }\end{array}$ & Mature \\
\hline & & \multicolumn{10}{|c|}{ Stage } \\
\hline \multirow[t]{6}{*}{$\overline{0-30}$} & $\mathrm{MST}_{0}$ & 98.4 & $89.6 \mathrm{~d}$ & $90.7 b$ & $90.3 \mathrm{c}$ & $138.6 \mathrm{c}$ & 96.4 & 97.0 & 114.6 & $105.8 \mathrm{~b}$ & $134.3 \mathrm{~b}$ \\
\hline & $\mathrm{MST}_{1}$ & 94.6 & $96.1 \mathrm{c}$ & $99.9 \mathrm{a}$ & $104.3 \mathrm{a}$ & $145.5 \mathrm{ab}$ & 94.1 & 100.3 & 119.2 & $124.7 \mathrm{a}$ & $150.0 \mathrm{a}$ \\
\hline & $\mathrm{MST}_{2}$ & 99.7 & $102.6 \mathrm{a}$ & $103.3 \mathrm{a}$ & $104.2 \mathrm{a}$ & $149.2 \mathrm{a}$ & 98.2 & 102.9 & 116.4 & $123.1 \mathrm{a}$ & $146.3 \mathrm{a}$ \\
\hline & $\mathrm{MPT}_{0}$ & 93.2 & $97.0 \mathrm{bc}$ & $88.8 \mathrm{~b}$ & $94.5 \mathrm{bc}$ & $141.1 \mathrm{bc}$ & 100.4 & 100.5 & 117.8 & $114.6 \mathrm{ab}$ & $127.5 \mathrm{c}$ \\
\hline & $\mathrm{MPT}_{1}$ & 94.1 & 99.9abc & $96.4 \mathrm{ab}$ & $97.6 \mathrm{~b}$ & $141.5 \mathrm{bc}$ & 98.3 & 101.9 & 111.3 & $118.2 \mathrm{ab}$ & $131.0 \mathrm{~b}$ \\
\hline & $\mathrm{MPT}_{2}$ & 93.5 & $101.4 \mathrm{ab}$ & $102.6 \mathrm{a}$ & $102.1 \mathrm{ab}$ & $145.9 \mathrm{ab}$ & 100.6 & 102.7 & 116.6 & $126.2 \mathrm{a}$ & $140.6 \mathrm{ab}$ \\
\hline \multirow[t]{6}{*}{$30-60$} & $\mathrm{MST}_{0}$ & 131.4 & $140.7 \mathrm{abc}$ & $138.3 \mathrm{c}$ & $130.7 b$ & $164.9 \mathrm{c}$ & 171.8 & 158.5 & $137.5 \mathrm{~b}$ & 162.9 & 179.3 \\
\hline & $\mathrm{MST}_{1}$ & 136.3 & $137.3 \mathrm{c}$ & $139.7 \mathrm{bc}$ & $136.0 \mathrm{a}$ & $172.5 \mathrm{ab}$ & 174.4 & 160.3 & $145.6 \mathrm{ab}$ & 172.5 & 182.2 \\
\hline & $\mathrm{MST}_{2}$ & 135.3 & $139.3 \mathrm{bc}$ & $142.8 \mathrm{a}$ & $137.4 \mathrm{a}$ & $174.0 \mathrm{a}$ & 169.5 & 156.7 & $139.2 b$ & 160.0 & 177.4 \\
\hline & $\mathrm{MPT}_{0}$ & 132.5 & $145.1 \mathrm{a}$ & $136.2 d$ & $130.8 b$ & $167.3 \mathrm{bc}$ & 179.8 & 171.0 & $140.6 \mathrm{~b}$ & 163.9 & 180.1 \\
\hline & $\mathrm{MPT}_{1}$ & 134.2 & $144.7 \mathrm{ab}$ & $140.8 \mathrm{ab}$ & $138.4 \mathrm{a}$ & $174.0 \mathrm{a}$ & 175.4 & 171.8 & $151.5 \mathrm{a}$ & 168.6 & 177.9 \\
\hline & $\mathrm{MPT}_{2}$ & 134.7 & $143.9 \mathrm{ab}$ & $141.3 \mathrm{ab}$ & $136.4 \mathrm{a}$ & $174.1 \mathrm{a}$ & 173.9 & 163.1 & $148.1 \mathrm{a}$ & 165.4 & 177.1 \\
\hline \multirow[t]{3}{*}{$0-30$} & Intercropping mode & ns & $* *$ & $\mathrm{~ns}$ & $\mathrm{~ns}$ & $\mathrm{~ns}$ & $\mathrm{~ns}$ & $\mathrm{~ns}$ & ns & ns & ns \\
\hline & Biochar & ns & $*$ & $* *$ & $*$ & $*$ & ns & $\mathrm{ns}$ & $\mathrm{ns}$ & $*$ & $* *$ \\
\hline & Intercropping $\times$ Biochar & $\mathrm{ns}$ & $* *$ & $*$ & $*$ & $*$ & ns & ns & ns & $*$ & * \\
\hline \multirow[t]{3}{*}{$30-60$} & Intercropping mode & ns & $*$ & ns & ns & ns & ns & ns & ns & ns & ns \\
\hline & Biochar & $\mathrm{ns}$ & ns & $* *$ & $* *$ & $* *$ & $\mathrm{~ns}$ & ns & $*$ & ns & $\mathrm{ns}$ \\
\hline & Intercropping $\times$ Biochar & ns & $*$ & $* *$ & $*$ & $*$ & ns & ns & $*$ & ns & $\mathrm{ns}$ \\
\hline
\end{tabular}

Explanations as in Table 2. 
Table 3 shows that the soil bulk density of the cultivated layer gradually increased in the early stage and later stage of the study. Table 4 shows the $S W S$ value at the $0-30 \mathrm{~cm}$ and 30-60 $\mathrm{cm}$ depth in each growth period for different treatments during the two growth seasons.

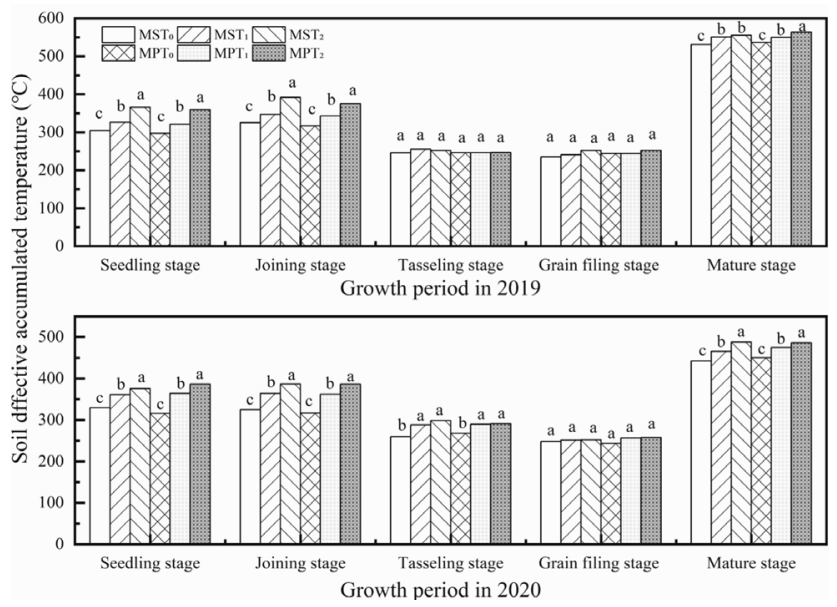

Fig. 3. Effect of biochar on the soil effective accumulated temperature at the $0-25 \mathrm{~cm}$ depth in different growth periods.

During the entire growth period, the SWS value increased with the increasing biochar content of the soil. The $S W S$ at the $0-30 \mathrm{~cm}$ depth did not increase significantly in the seedling stage but it did increase significantly in the tasselling stage (2019) and grain filling stage (2019 and 2020). In the tasselling stage, the $S W S$ value of the $0-30 \mathrm{~cm}$ soil depth increased by $15.5 \%$ for the treatment of the MP system in which 30 tha $^{-1}$ biochar was applied at a $0-30 \mathrm{~cm}$ depth, but there was no significant difference in 2020 according to Table 4. For different soil depths, the impact of biochar on soil water storage was mainly concentrated in the $0-30 \mathrm{~cm}$ layer, whereas the impact of biochar on the 30-60 cm layer was relatively weak. It may be observed that biochar mainly affected the top soil layer, and the $S W S$ value was optimal at an application rate of $30 \mathrm{tha}^{-1}$.

It may be observed from Fig. 3 that $T_{1}$ and $T_{2}$ significantly increased the soil effective accumulated temperature (SEAT) in the seedling and jointing stages. SEAT increased as the amount of biochar added increased. The maximum increase in the rate was obtained for treatment $T_{2}$ under the MP system at the seedling stage, and the increase rate was more than $20 \%$ across the two years of the study. During the tasselling and grain filling stage, biochar did not significantly impact the SEAT. In the mature period, the effect of different biochar application rates on the SEAT was significant, but the observed increase in SEAT was not as pronounced in the mature period as it was in the previous period. Indeed, the greatest increase observed in the mature stages was only $5.2 \%$. Due to less rainfall and the leaf area index, biochar can demonstrate significant effects on SEAT in the early period of plant growth, and it was weaker in the middle and later periods when rainfall was sufficient and the $S W S$ value was higher.
Figs 4 and 5 show that $T_{1}$ and $T_{2}$ significantly reduced the content of ammonium nitrogen and nitrate nitrogen in the soil at the seedling stage, for the two intercropping systems. Ammonium nitrogen was reduced on average by $36.6 \%$, while nitrate nitrogen was reduced by $42.4 \%$ over the period of the two-year study. This shows that biochar exhibited an inhibitory effect on the soil mineral nitrogen content during the early stage of growth, which reduced the soil nutrient supply for crops. In the jointing stage, the inhibitory effect of biochar on soil nitrogen weakened, but the soil mineral nitrogen content was still lower than that of $\mathrm{T}_{0}$. During the tasselling period, the biochar released ammonium nitrogen and subsequently increased the nitrate nitrogen in the soil. The mineral nitrogen content of the $T_{1}$ and $T_{2}$ treatments was greater than that of the $T_{0}$ treatment. During the grain filling stage, the content of ammonium and nitrate nitrogen in the soil under the $T_{1}$ and $T_{2}$ treatments were significantly higher on a continuous basis than those under $\mathrm{T}_{0}$, and the soil ammonium and nitrate nitrogen content of the soybean (MS-S) and peanut (MP-P) ridges was significantly higher than that of the corn ridges. At the maturity stage, the soil mineral nitrogen content under the $\mathrm{T}_{1}$ and $\mathrm{T}_{2}$ treatments was still higher than that under $\mathrm{T}_{0}$ conditions. It may be observed that from the early stage to the middle and late stages of growth, the effect of biochar on the soil mineral nitrogen content transitioned from adsorption to release, which was conducive to higher crop yield especially for peanut and soybean yield.

\section{DISCUSSION}

Because biochar has a rich pore structure, it provides more space for water adsorption in the soil, the application of biochar to cultivated soil can reduce soil bulk density but increase the $S W S$ value and reduce water evaporation (Zhang et al., 2016, Verheijen et al., 2019). The results of this experiment show that the application of biochar in the soil at the early stage of crop growth had no significant effect on soil water storage, this mainly stemmed from lower rainfall in the early growth stage. However, the effect of soil water movement and rainfall at a later growth stage caused the water retention capacity of biochar to be realized, and the $S W S$ values of the biochar treatments in the middle and late growth stages increased significantly. The conclusions above were consistent with the results of a previous study (Ouyang et al., 2013). Compared with the SWS value in the $30-60 \mathrm{~cm}$ soil layer, the increase in the $S W S$ value of the biochar treatment in the $0-30 \mathrm{~cm}$ soil layer was more pronounced, which is consistent with the results of previous research (Bruun et al., 2014). Thus, biochar plays an important role in improving soil moisture status, which is important for rain-fed agriculture given that rainfall is a key factor affecting water-holding capacity. 

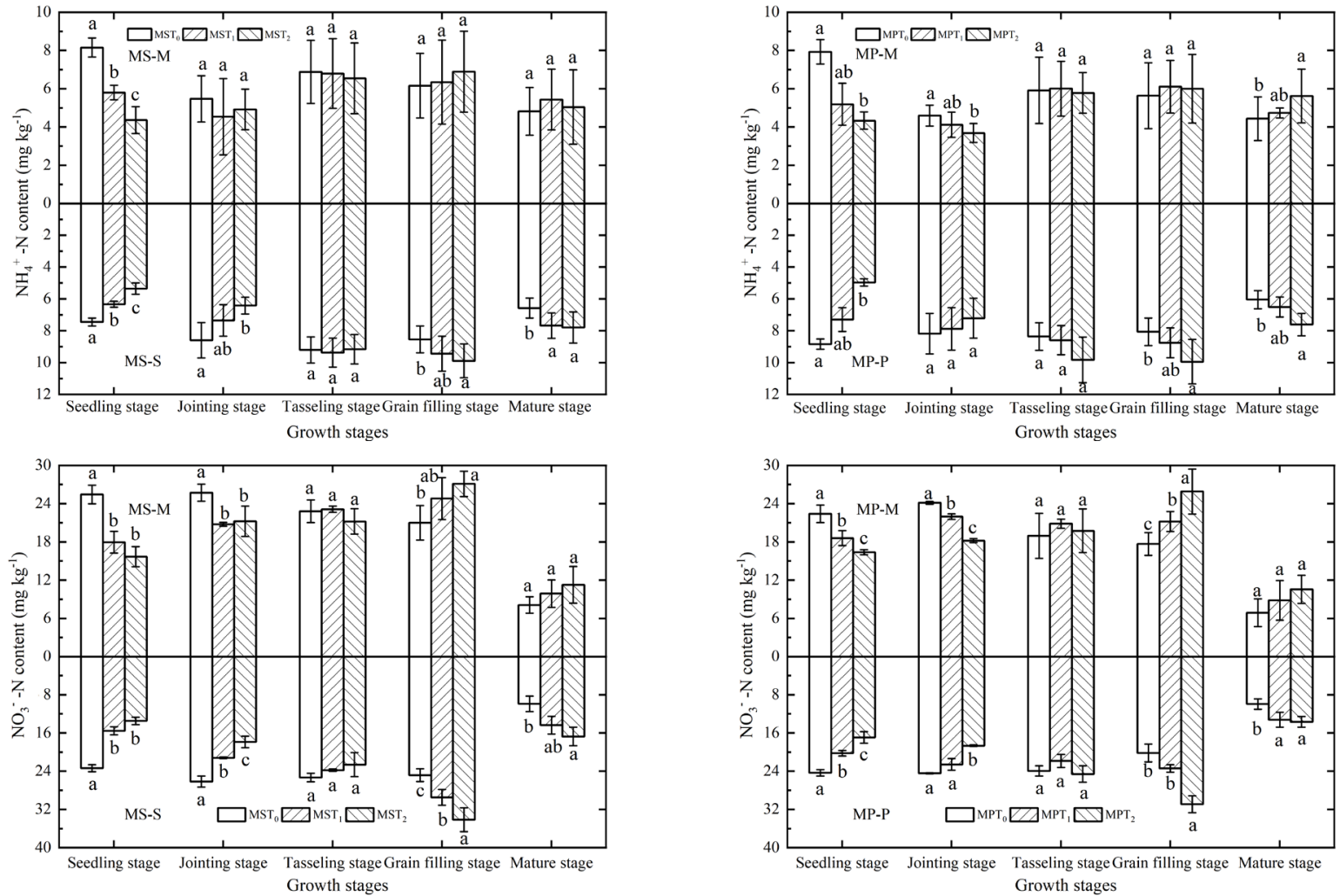

Fig. 4. Effect of biochar on the mineral nitrogen content in the intercropping systems in 2019. MS-M indicates maize ridges; MS-S indicates soybean ridges; MP-M indicates maize ridges; MP-P indicates peanut ridges.
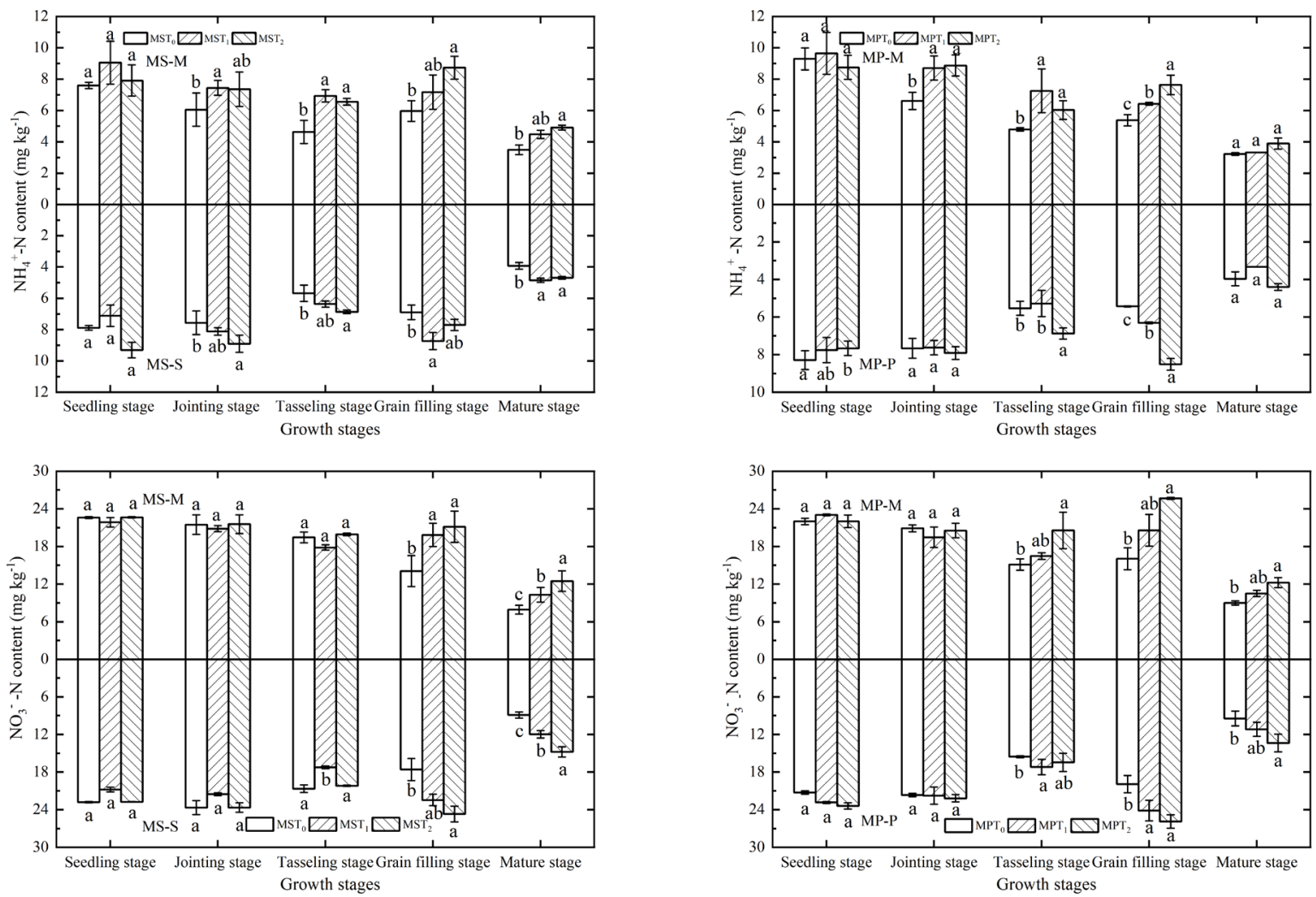

Fig. 5. Effect of biochar on the mineral nitrogen content in the intercropping systems in 2020. MS-M indicates maize ridges, MS-S indicates soybean ridges, MP-M indicates maize ridges, MP-P indicates peanut ridges. 
The soil temperature is mainly driven by solar radiation. Our results show that the SEAT of biochar treatments increased significantly during the seedling and jointing stages, which mainly stemmed from the fact that the mixed application of biochar into the soil deepened the soil colour (Paz-Ferreiro et al., 2014). During this period, crop plants were small, and the leaves provided little shade, which permitted the soil to absorb solar radiation, leading to increases in the soil temperature. However, in the middle and late stages of crop growth under intercropping, the leaves provided extensive shading, which severely weakened the effect of soil colour on soil temperature (Sheats., 2014). Therefore, the temperature-increasing effect of biochar in the later growth period was not pronounced. Our experiments revealed that biochar had the weakest effect on SEAT during the tasselling and grain filling periods. The effect of soil temperature may also have been weakened by the increase in soil water storage associated with biochar during the tasselling and grain filling growth periods.

The soil mineral nitrogen level indicates the soil nitrogen supply capacity and can be used to evaluate soil fertility. The total nitrogen content of biochar is high, but the mineral nitrogen content is very low, it was found to be even negligible when compared with to the mineral nitrogen content in the original soil (Wu et al, 2020). Therefore, the performance activity of biochar to in the soil is mainly to adsorb mineralized nitrogen, rather than to supplement soil mineralized nitrogen. Also, the surface of biochar is rich in functional groups, which have the potential to adsorb soil nutrients and reduce nutrient loss. This experiment revealed that the soil mineral nitrogen content of the biochar treatment was significantly reduced in the early growth stage because of the significant absorption effect with regard to inorganic fertilizer, which was consistent with the research results by Wu et al. (2019). As crops grow, biochar can desorb mineral nitrogen in the soil, this results in higher soil nutrient content. Additionally, under intercropping conditions involving grasses and legumes, legumes can be used to provide nutrients for gramineous crops, and biochar can fix nutrient secretions from leguminous nodules to continuously enhance nitrogen uptake for gramineous crops (Xia et al., 2021). Therefore, the soil mineral nitrogen content was significantly higher for the middle and late growth stages in the biochar treatment than that in the $\mathrm{T}_{0}$ treatment. It was also found that the soil mineral nitrogen content decreased rapidly in the middle and late growth period. There are two possible explanations for the rapid decrease in the soil mineral nitrogen content during the mature period: 1) the soil nitrogen was absorbed by crops, and 2) heavy rainfall promoted the leaching of nitrate nitrogen given that the mature period coincided with the local flooding season (Dai et al., 2019; Xia et al., 2020). Studies have shown that biochar addition increased the carbon-nitrogen ratio of the soil, as well as micronutrient elements such as $\mathrm{B}$ and Mo, so $\mathrm{N}$ uptake by leguminous crop rhizobia was also enhanced (Rondon et al., 2007, Guerena et al., 2015). By improving the absorption of
$\mathrm{N}$, $\mathrm{P}$, and $\mathrm{K}$ elements in plants, biochar also inhibited cation leaching including $\mathrm{NH}_{4}^{+}, \mathrm{K}^{+}$, and $\mathrm{Ca}^{2+}$ with water (Van et al., 2015). This experiment also revealed that biochar treatment not only increased the mineral nitrogen content of the soil in the soybean and peanut rows but also alleviated the nutrient uptake competition between gramineous crops and legumes in the intercropping system. Li et al. (2006) found that biochar treatment enhanced the root interactions between the two crops in the intercropping system and increased yields. Our results show that biochar significantly increased the overall output of the intercropping system. The yields of soybeans and peanuts increased significantly, as the amount of biochar applied increased, and there was no notable difference in the corn yield between $T_{1}$ and $T_{2}$. Thus, in the MS intercropping mode, the corn yield of $T_{2}$ was less than that of $\mathrm{T}_{1}$, which was in line with the results of a previous study (Gajda et al., 2016; Dai et al. 2019). In summary, the application of biochar can increase the output of the intercropping system under both MS and MP conditions.

\section{CONCLUSIONS}

1. The effects of biochar application on the effective accumulated temperature of soil were weakened for the middle and late growth stages. As influenced by rainfall, biochar significantly increased soil water storage in the $0-30 \mathrm{~cm}$ soil layer.

2. From the early stage to the middle and late stages, the effect of biochar on soil mineral nitrogen content transitioned from adsorption to release, which met the crop growth requirement.

3. The soil mineral nitrogen content of soybean and peanut ridges was significantly higher than that of the corn ridges.

4. The total yield of maize/soybean increased by 12.8 $13.8 \%$ and the total yield of maize/peanut intercropping increased by $11.8-13.8 \%$ relative to the treatment without biochar.

Conflict of interest: The authors do not declare any conflict of interest

\section{REFERENCES}

Abel S., Peters A., Trinks S., Schonsky H., Facklam M., and Wessolek G., 2013. Impact of biochar and hydrochar addition on water retention and water repellency of sandy soil. Geoderma, 202, 183-191,

https://doi.org/10.1016/j.geoderma.2013.03.003

Bruun E.W., Petersen C.T., Hansen E., Holm J.K., and Hauggaard-Nielsen H., 2014. Biochar amendment to coarse sandy subsoil improves root growth and increases water retention. Soil Use Manage., 30(1), 109-118, https://doi.org/10.1111/sum.12102

Chen Z., Cui H., Wu P., Zhao Y., and Sun Y., 2010. Study on the optimal intercropping width to control wind erosion in North China. Soil Till. Res., 110(2), 230-235, https://doi.org/10.1016/j.still.2010.07.014 
Dai W., Wang L., Ismail K., Wang X., and Li Z., 2019. Effects of straw mulching and biochar addition on soil temperature and maize yield (in Chinese). Chin. J. Ecol., 3, 719-725.

Gajda A.M., Czyz E.A., and Dexter A.R., 2016. Effects of longterm use of different farming systems on some physical, chemical and microbiological parameters of soil quality. Int. Agrophys., 30(2), 165-172, https://doi.org/10.1515/intag-2015-0081

Green D.S., Boots B., Carvalho J.D.S., and Starkey T., 2019. Cigarette butts have adverse effects on initial growth of perennial ryegrass (gramineae: Lolium perenne L.) and white clover (leguminosae: Trifolium repens L.). Ecotox. Environ. Safe., 182, 109418, https://doi.org/10.1016/j.ecoenv.2019.109418

Guerena D.T., Lehmann J., and Thies J.E., 2015. Partitioning the contributions of biochar properties to enhanced biological nitrogen fixation in common bean (Phaseolus vulgaris). Biol. Fert. Soils, 51, 479-491, https://doi.org/10.1007/s00374-014-0990-Z

Hussain S., Liu T., Iqbal N., Brestic M., Pang T., Mumtaz M., and Yang W., 2020. Effects of lignin, cellulose, hemicellulose, sucrose and monosaccharide carbohydrates on soybean physical stem strength and yield in intercropping. Photoch. Photobio. Sci., 19(4), 462-472, https://doi.org/10.1039/C9PP00369J

Lehmann J., Rillig M.C., Thies J., Masiello C.A., Hockaday W.C., and Crowley D., 2011. Biochar effects on soil biota. A review. Soil Biol. Biochem., 43(9), 1812-1836, https://doi.org/10.1016/j.soilbio.2011.04.022

Liao H., Li Y., and Yao H., 2019. Biochar amendment stimulates utilization of plant-derived carbon by soil bacteria in an intercropping system. Front. Microbiol., 10, 1361, https://doi.org/10.3389/fmicb.2019.01361

Li L., Sun J., Zhang F., Guo T., Bao X., Smith F.A., and Smith S.E., 2006. Root distribution and interactions between intercropped species. Oecologia, 147(2), 280-290, https://doi.org/10.1007/s00442-005-0256-4

Liu X., Zhang A., Ji, C., Joseph S., Bian R., Li L., and PazFerreiro J., 2013. Biochar's effect on crop productivity and the dependence on experimental conditions-a meta-analysis of literature data. Plant Soil, 373(1), 583-594, https://doi.org/10.1007/s11104-013-1806-x

Liu Y., Wang J.G., Guo F., Tang C.H., Yang S., Geng Y., Meng J.J., Li X.G., Zhang J.L., and Wan S.B., 2020. Effects of corn and peanut intercropping on dry matter accumulation and nitrogen absorption and utilization of crops (in Chinese). Chinese Journal of Oil Crops, 42(06), 994-1001.

Major J., Rondon M., Molina D., Riha S.J., and Lehmann J., 2010. Maize yield and nutrition during 4 years after biochar application to a Colombian savanna oxisol. Plant Soil, 333(1), 117-128, https://doi.org/10.1007/s11104-010-0327-0

Miao Y., Stewart B., and Zhang F., 2011. Long-term experiments for sustainable nutrient management in China. Agron. Sustain. Dev., 31(2), 397-414, https://doi.org/10.1051/agro/2010034

Milly.P.C.D., 1994. Climate, soil water storage, and the average annual water balance. Water Resour. Res., 30(7), 21432156, https://doi.org/10.1029/94WR00586

Oswald A., Ransom J.K., Kroschel J., and Sauerborn J., 2002. Intercropping controls Striga in maize based farming systems. Crop Prot., 21(5), 367-374, https://oi.org/10.1016/S0261-2194(01)00104-1
Ouyang L., Wang F., Tang J., Yu L., and Zhang R., 2013. Effects of biochar amendment on soil aggregates and hydraulic properties. J. Soil Sci. Plant Nut., 13(4), 991-1002, https://doi.org/10.4067/S0718-95162013005000078

Paz-Ferreiro J., Fu S., Méndez A., and Gascó G., 2014. Interactive effects of biochar and the earthworm Pontoscolex corethrurus on plant productivity and soil enzyme activities. J. Soil Sediments, 14(3), 483-494, https://doi.org/10.1007/s11368-013-0806-z

Pirhofer-Walzl K., Rasmussen., J., Høgh-Jensen H., Eriksen., J., Søegaard., K., and Rasmussen J., 2012. Nitrogen transfer from forage legumes to nine neighbouring plants in a multi-species grassland. Plant Soil, 350(1), 71-84, https://doi.org/10.1007/s11104-011-0882-z

Rondon M.A., Lehmann J., and Ramirez J., 2007. Biological nitrogen fixation by common beans (Phaseolus vulgaris L.) increases with bio-char additions. Biol. Fert. Soils, 43, 699708, https://doi.org/10.1007/s00374-006-0152-z

Sekiya N., Araki H., and Yano K., 2011. Applying hydraulic lift in an agroecosystem: forage plants with shoots removed supply water to neighboring vegetable crops. Plant Soil, 341(1), 39-50, https://doi.org/10.1007/s11104-010-0581-1

Sheats J., 2014. Performance quantification of extensive green roof substrate blend: Expanded shale and biochar. [Masters Thesis], James Madison University.

Sohi S. P., Krull E., Lopez-Capel E., and Bol R., 2010. A review of biochar and its use and function in soil. Adv. Agron., 105, 47-82, https://doi.org/10.1016/S0065-2113(10)05002-9

Van Z., Rose T., and Herridge D., 2015. Enhanced biological $\mathrm{N}_{2}$ fixation and yield of faba bean (Vicia faba L.) in an acid soil following biochar addition: dissection of causal mechanisms. Plant Soil, 395, 7-20, https://doi.org/10.1007/s11104-015-2427-3

Verheijen F.G., Zhuravel A., Silva F.C., Amaro A., Ben-Hur M., and Keizer J.J., 2019. The influence of biochar particle size and concentration on bulk density and maximum water holding capacity of sandy vs sandy loam soil in a column experiment. Geoderma, 347, 194-202, https://doi.org/10.1016/j.geoderma.2019.03.044

Wu Q., Chen T., Chi D., Xia G., Sun Y., and Song Y., 2019. Increasing nitrogen use efficiency with lower nitrogen application frequencies using zeolite in rice paddy fields. Int. Agrophys., 33(2), 263-269, https://doi.org/10.31545/intagr/109545

Wu Q., Chi D., Xia G., Chen T., Sun Y., and Song Y., 2019. Effects of zeolite on drought resistance and water-nitrogen use efficiency in paddy rice. J. Irrig. Drain. E., 145(11), 04019024, https://doi.org/10.1061/(ASCE)IR.1943-4774.0001420

Wu Q., Wang Y., Chen T., Zheng J., Sun Y., and Chi D., 2020. Soil nitrogen regulation using clinoptilolite for grain filling and grain quality improvements in rice. Soil Till. Res., 199, 104547 , https://doi.org/10.1016/j.still.2019.104547

Xia G., Wang Y., Hu J., Wang S., Zhang Y., Wu Q., and Chi D., 2021. Effects of supplemental irrigation on water and nitrogen use, yield, and kernel quality of peanut under nitrogen-supplied conditions. Agric. Water Manag., 243, 106518 , https://doi.org/10.1016/j.agwat.2020.106518 
Xu Y., Sun L., Gao Z., Zhai H., and Du Y., 2020. Research on the correlation between overall respiration changes of grapevine buds and roots and effective accumulated air and soil temperatures (in Chinese). Acta Plant Physiol., 56(04), 799-806.

Zhang X.N., Chen P., Pang T., Du Q., Fu Z.D., Zhou Y., Ren J.Y., Yang W.Y., and Yong T.W., 2017. The effects of dry matter accumulation, distribution and yield in the maize/ soybean and maize/peanut intercropping system (in Chinese). J. Sichuan Agric. Univ., 35(4), 484-490. effect on water evaporation and hydraulic conductivity in sandy soil. Pedosphere, 26(2), 265-272,

https://doi.org/10.1016/S1002-0160(15)60041-8 